1993

\title{
Durkheim's Cult of the Individual as Civil Religion: its Appropriation by Erving Goffman
}

James J. Chriss

Cleveland State University

Follow this and additional works at: https://engagedscholarship.csuohio.edu/clsoc_crim_facpub

Part of the Criminology Commons

How does access to this work benefit you? Let us know!

Publisher's Statement

This is an Author's Accepted Manuscript of an article published in Sociological

Spectrum,1993,available online: http://www.tandfonline.com/doi/abs/10.1080/

02732173.1993.9982028\#.VBC9rWMXMuQ.

\section{Repository Citation}

Chriss, James J., "Durkheim's Cult of the Individual as Civil Religion: its Appropriation by Erving Goffman" (1993). Sociology \& Criminology Faculty Publications. 97.

https://engagedscholarship.csuohio.edu/clsoc_crim_facpub/97

This Article is brought to you for free and open access by the Sociology \& Criminology Department at EngagedScholarship@CSU. It has been accepted for inclusion in Sociology \& Criminology Faculty Publications by an authorized administrator of EngagedScholarship@CSU. For more information, please contact library.es@csuohio.edu. 


\title{
DURKHEIM'S GULT \\ OF THE INDIVIDUAL AS CIVIL \\ RELIGION: ITS APPROPRIATION \\ BY ERVING GOFFMAN
}

\author{
JAMES J. CHRISS \\ University of Pennsylvania
}

The purpose of this article is to provide a systematic analysis of the place of Durkheim's "cult of the individual" in Erving Goffman's sociology. ${ }^{7}$ I have reviewed the most pertinent aspects of Durkheim's sociology of religion. This article discusses and/or analyzes the development of the cult of the individual primarily within the context of Durkheim's (1951) monograph on suicide; Durkheim's notions of sacred, profane, and ritual; Coffman's two-pronged intellectual heritage; and Goffman's "Communication Conduct in an Island Community" (1953) with respect to several key Durkheimian concepts. Also discussed are several important secondary analyses-primarily those of Jurgen Habermas and Stanford Lyman-which help to further delineate the conditions of the Durkheim-Goffman link. The final section applies Coffman's sociology to the case of Evangelicalism and "political civility."

\section{DURKHEIM'S SOGIOLOGY OF RELIGION}

Emile Durkheim's sociology was thoroughly imbued with concerns over religion and its role in societal change. As Pearce (1989) has noted, Durkheim argued-especially in his major treatise on religion, The Elementary Forms of the Reli-

A version of this article was presented at the annual meeting of the Society for the Sclentific Study of Religıon, Pittsburgh, PA, November 1991. I thank Teresa Labov, Bruce Wearne, Arthur Greil, and three anonymous reviewers for helpful comments on several earlier drafts.

"As will be discussed more fully below, the phrase "cult of the individual" refers to Durkheim's view of societal progression and the concomitant shift of emphasis toward the sanctity of the individual. There has been some terminological confusion surrounding this general concept, however: besides "cult of the individual" or "individualism," a number of other phrases have been used nearly interchangeably by a variety of translators (and even by Durkheim himself), e.g., "religion of humanity," "dignity of the human person," "cult of personality," and "cult of man" (for an excellent discussion of these and related terminological matters, see Pickering [1984, pp. 481-487]). For the sake of uniformity, then, I will, for the most part, follow Marsike's (1987) usage of "cult of the individual." 
gious Life-that everything social begins with religion, and that there is no known society that does not possess or exhibit some form of religion.

Durkheim $(1938,1951,1954,1984)$ was fascinated with the power of religion and religious ideals in shaping the lives of a community of believers. His now-famous distinction between preliterate and advancing or modern societies hinged upon a formulation that posited very different forms of solidarity corresponding with their respective species of society. That is to say, preliterate societies are dominated by a mechanical solidarity whose source is homogeneity, conformity of its members through harsh and repressive sanctions (i.e., penal law), and a collective consciousness that completely envelops and subordinates the individual to the society. In contrast, organic solidarity represents a form of moral development wherein solidarity is forged through heterogeneity, interdependence of societal members, a shift toward restitutive law, and the emergence of the division of labor.

As one might expect, the role of religion in these societies corresponds with the nature of social solidarity vis-à-vis this mechanical-to-organic progression. As stated above, although Durkheim was concerned with, and even somewhat in awe of, religion, he felt that traditional religion was on the wane and would not persist in Europe. In fact, Durkheim (1954, p. 475) once said that "... the old gods are growing old or already dead, and others are not yet born."

But we immediately sense a paradox in Durkheim's sociology of religion. On the one hand, Durkheim says that everything begins with religion and that it will always be a component of social life. On the other hand, however, he sees the force of religion slowly waning and a general trend of secularization emerging as societies move toward organic solidarity. How can these seemingly disparate positions in Durkheim's thought be reconciled?

Durkheim's attempt to account for the twin phenomena of ongoing secularization in light of the staying power of religion as a primordial force in modern society is at heart the problem of "man and society" and the nature of individualism. Rather than doing away with religion or suggesting that it would soon become an analytically inconsequential category, Durkheim merely shifted the quiddity of the religious force 
from societal representation (as per mechanical solidarity) to the sanctity of the individual (as per organic solidarity). This is most clearly illustrated in the progression of Durkheim's thought beginning in his monograph on suicide (Durkheim 1951) and extending through his last great work, The Elementary Forms of the Religious Life (1954).

\section{SUICIDE}

Let us turn to one passage in particular from Suicide (1951, p. 341) that stands out as a seemingly exemplary instance of Durkheim's functionalism:

Suicide is, then, a transformed and attenuated homicide. ... It would even seem that one should not try to restrain its scope by prohibitive measures. ... It is a safety-valve which is useful to leave open. In short, suicide would have the very great advantage of ridding us of a number of useless or harmful persons without social intervention, and hence in the most simple and economical way. Is it not better to let them put themselves out of the way voluntarily and quietly, than to force society to eject them from its midst by violence?

Now anyone who has given Suicide a thorough and thoughtful reading should recognize instantly that the naive functionalism evident in the above quote is merely rhetorical. In point of fact, Durkheim goes on to argue against such notions as these.

However, at least one strand of thought from the quote seems in line with what Durkheim has been theorizing in more general terms, namely his notion that as social solidarity progresses from mechanical to organic the society's laws tend to transform from harsh and repressive to more lenient and restitutive. According to this line of thinking, one might expect Durkheim to suggest in Suicide that prohibitive measures against suicide should wane as a society becomes more modern. But this, in fact, is not the case. Rather, Durkheim is careful to construct an argument against the notion that condemnation against suicide lessens as societies advance. After dedicating the first parts of the book to the verification that suicide is indeed a social, rather than a psychological, phenomenon, 
Durkheim approaches this question by asking, to what degree should suicide be considered a criminal act?

To answer this, Durkheim takes a brief historical digression, a retreat through time to compare how different societies and ages have viewed suicide. Durkheim's (1951, p. 326) strategy, then, is to discover "... how peoples actually have estimated suicide morally in the course of history; then try to find the reasons for this estimate." He (1951, p. 327) begins with the assessment that "as soon as Christian societies were formed, suicide was formally forbidden in them." From 452 A.D. in the council of Arles to Prague in 563 and on through to the throne of Louis XIV in 1670, Durkheim traces the record of each society's moral and legal sanctionings against suicide. As might be expected, Durkheim finds a general trend: with the progression of time there has been a concomitant change from repressive, barbaric punishment against suicide or its attempt toward, if not decriminalization, at least the lessening of the penalty. Thus, for example, Durkheim (1951, p. 329) shows that according to the 1881 New York penal code suicide was still listed as a crime, but "in spite of this, punishment has been given up for practical reasons, since the penalty could in no way affect the guilty person."

What Durkheim (1951, p. 332) is leading to here is that, beyond the primitive stage, legislation concerning suicide falls into two broad categories. First, in earlier societies (specifically the Greco-Latin city-states) the state stands in complete domination over the individual: "...the individual is forbidden to destroy himself on his own authority; but the State may permit him to do so." Since the collective conscience is still strong here, the individual who takes his or her own life is in effect transgressing against the state for not collaborating beforehand with the "organs of life."

In the second, more modern period-with the emergence of organic solidarity-Durkheim (1951, p. 333) suggests that "condemnation [against suicide] is absolute and universal." In this new morality not even the state has the right or privilege to take (or allow the taking of) a life. With the progression of morality, of organic solidarity, suicide is now viewed as an immoral act in and of itself. Thus, in answer to his own rhetorical query posed earlier, Durkheim responds by saying that "with the progression of history the prohibition [against suicide] becomes 
more strict." It is by this presentation of the historical record that Durkheim shows how moral evolution affects and directs a society's legislation against suicide.

Durkheim describes this trend toward greater condemnation of suicide as resulting from the change of focus in modern society away from the state and more toward the human personality. The human personality has, in effect, become sacred, and it is exalted to a level even above and beyond that of society itself. Whereas before the state had rights over the individual in terms of allowing a suicide, today the dignity of the self transcends all, including that of the individual. Durkheim (1951, pp. 333-334) explains this seemingly paradoxical statement as follows:

But today [the individual] has acquired a kind of dignity which places him above himself as well as above society. So long as his conduct has not caused him to forfeit the title of man, he seems to us to share in some degree that quality sui generis ascribed by every religion to its gods which renders them inviolable by everything mortal.

Thus, according to Durkheim, the individual-that storehouse of the human personality-becomes sacrosanct. Men and women now, as a result of the division of labor and the onset of organic solidarity, worship each other's quality of "otherness." The taking of one's own life is no longer simply a transgression against the state; it is now the ultimate sacrilege. Morality rests within the very otherness of the other and of ourselves; the "cult of human personality" is the new, modernday object of worship. To strike against it by committing suicide is to strike against the very heart and soul of humanity.

Durkheim makes, in my own estimation, a compelling case for the move toward a greater emphasis on the sacred nature of the individual. There seems little evidence to deny his suggestion that beginning in antiquity-in the original state of affairs-society is viewed as everything while the individual is nothing. Things are done for society's sake; individuals are simply means for achieving society's ultimate ends or purposes. But over time, as he has shown, the face of society changes; the very nature of morality itself goes through a metamorphosis, growing from infancy to adulthood. It is at this point where Durkheim really begins to pull it all together theo- 
retically, where he begins to incorporate in a very meaningful way the important strands of thought from his earlier work in Division of Labor. It is a passage worth quoting in its entirety. As Durkheim (1951, p. 336) explains:

But gradually things change. As societies become greater in volume and density, they increase in complexity, work is divided, individual differences multiply, and the moment approaches when the only remaining bond among the members of a single human group will be that they are all men. Under such conditions the body of collective sentiments inevitably attaches itself with all its strength to its single remaining object, communicating to this object an incomparable value by so doing. Since human personality is the only thing that appeals unanimously to all hearts, since its enhancement is the only aim that can be collectively pursued, it inevitably acquires exceptional value in the eyes of all. It thus rises far above all human aims, assuming a religious nature.

Thus the cult of the individual comes to full fruition. ${ }^{2}$ This new religion of man is not an egoistical, individualistic celebration of human qua human (à la standard utilitarianism), it is, rather, this notion of a shared moral community. It is the realization that the human personality ordains within each of us a moral dignity that transcends and goes beyond the claims of any person or thing, including the state. But at the same time the essence of this morality-this ideal that subordinates us all to the general interests of humanity but that simultaneously draws each of us beyond ourselves as well-is not possessible within us as individuals; rather it is an essence set apart, sui generis. As Durkheim (1951, p. 337) explains, "Our dignity as moral beings is therefore no longer the property of the city-state; but it has not for that reason become our property, and we have not acquired the right to do what we wish with it. How

${ }^{2}$ Although I draw primarily from Suicide in tracing the development of the cult of the individual, one should note that Durkheim was involved in similar discussions in Professional Ethics and Civic Morals (1957, pp. 69-72) and Moral Education (1961, pp. 6-12). For excellent summaries of these latter treatments see, respectively, Lukes (1972, pp. 268-274) and Mestrovic (1988, pp. 134-140). Finally, Marske (1987) provides perhaps the most extensive discussion of the progression of Durkheim's thought on moral individualism. 
could we have such a right if society, the existence greater than ourselves, does not have it?" Hence, Durkheim shows that suicide is indeed an immoral act because no one has the right to deny oneself this religion of man.

\section{THE SACRED, THE PROFANE, AND RITUAL}

One of Durkheim's (1954) best-known distinctions is that of sacred versus profane. All societies employ symbols that are externalized vehicles for the representation of intersubjective feelings and collective sentiment. Symbols perpetuate the social order, and the songs we sing, the prayers we pray, the national anthems that stir us to rise in unison, even the particular or secret handshake of a special group-all these reinforce the social solidarity (Tiryakian 1978, p. 220).

The most compelling sentiment for Durkheim (1954) in providing the foundation of group identity is the religious sentiment, i.e., the feelings of the sacred. Human cultures (or belief systems) tend to divide the world and lead individuals to perceive and experience two categories: 1) the sacred-toward sacred entities we take an affective or expressive orientation that views these objects as ends in themselves (e.g., totems); 2) the profane-those things and attitudes characteristic of the economic, rather than the religious, life. Profane objects elicit instrumental and/or utilitarian orientations; they are means toward some further goal. Economic life is dull, monotonous, and "generally of a very mediocre intensity" (Durkheim 1954, p. 247). The understanding of society and the beliefs and meanings that group members hold as collective representations of that society reside in the religious life. Beyond the rational calculations of economic life, the partaking of ritual in collective ceremonies and other dramatic occasions binds societal members together in a form of solidarity that is affective, marked by periods of festivity and enthusiasm.

Ritual, then, is the mechanism by which members partaking of the religious life recreate the crescendo of collective sentiment forged around the symbolic understanding of mana, or the soul. Humans have always (but especially so in modern times) felt the urge to transcend the conditions of the mundane world of the economic life toward the extraordinary 
world of the sacred, because it is in these times of collective stimulation through ritual that primordial and ultimate understandings of being in the world are obtainable. Tiryakian (1978, p. 220) is correct, I believe, when he stated that Durkheim's (1954) analysis, although concentrating on primitive tribes and their relation to the sacred, is relevant to the case of modern society. It is especially relevant in the case of Goffman's sociology.

\section{GOFFMAN'S INTELLECTUAL LINEAGE}

There are two strands of thought undergirding Erving Goffman's sociology. ${ }^{3}$ One of these is the senior line of phenomenological scholarship that MacCannell $(1983$, p. 11) has described as "the Husserl-Heidegger-Sartre-Goffman succession." This particular strand of phenomenology (as opposed to the Schutz-Berger and Luckman variety) attempts to describe the nature of intersubjective understanding in the realm of the everyday and mundane. Current phenomenological sociology as seminally derived from Husserl has progressed through a variety of stages, most importantly "existentialism" in the form of, e.g., Heidegger and Sartre, and "deconstructionism" by way of, e.g., Merleau-Ponty and Laing (as well as various other forms of revision and update, e.g., Vaitkus [1991]). These revisions and critiques of the original Husserlian project appear in Goffman's work in the guise of, e.g., "frames" and "multiple realities" (1974, 1979, 1981), "signs" and "being-with" (1961b, 1971), the structure and phenomenon of the social "self" (1959, 1961a, 1963a), and intersubjective understanding of the other, be it via either the everyday and mundane (e.g., the practical or fiduciary attitude), or manipulated and "strategic" interaction (1963b, 1969, 1971).

The second of Goffman's intellectual lineages, and the one with which this study is primarily concerned, hails from British social anthropology and, of course, the work of Emile

\footnotetext{
${ }^{3}$ More to the point, these are the two major strands of Goffman's thought that, I emphasize, are most important in understanding his view of the individual and morality in modern society. There are other influences, of course; in several recent statements, Burns (1992) and Stein (1991) illustrate how Durkheim, Simmel, the Chicago School, animal ethology, and linguistic philosophy all contributed in important ways to Goffman's oeuvre.
} 
Durkheim (Collins 1986, 1988; MacCannell 1990). Although receiving his Ph.D. in sociology from Chicago, Goffman nevertheless eschewed the training in symbolic interactionism for which that department was famous. Hence, instead of Blumer or Mead, Goffman chose to study under the anthropologist/sociologist Lloyd Warner, himself heavily influenced by Durkheim (Collins 1980, 1986; Hannerz 1980).

Although the two intellectual lines as discussed above are readily evident and distinct, I argue that Durkheim's notion of ritual played the greatest part in informing Goffman's theories concerning social interaction and order. ${ }^{*}$ Goffman's formulation of social action secularizes religious morality by exhibiting how individuals are imbued with a variety of competencies at the level of the interaction order, thereby following Durkheim's own theories of the shift toward an increasing sanctification of the individual.

It should also be stated that, although distinct, the two strands of Goffman's thought-phenomenological-existential and sociological-are not necessarily antithetical. Edward Trryakian (1961) has argued, for example, that although "existentialism" and "sociologism" are different approaches to the question of "the individual and society," the two have successfully been brought together by Emile Durkheim. It is suggested that Goffman has indeed reconciled these two approaches in his theory by embracing, again, the Durkheimian formulation of ritual.

\section{DURKHEIM AND GOFFMAN: A BEGINNING}

I begin this section with a discussion of Goffman's (1953) dissertation, because it is here that some important insights are afforded with respect to both Goffman's relation to the thought of Emile Durkheim and his attempt to explicate the

${ }^{4}$ Although the argument of a Durkheim-Goffman link is certainly not new or novel (see, e.g., Collins 1975, 1980; Collins and Makowsky 1972; Miller 1982; Mitchell 1978), I intend to clarify and update the argument along several dimensions. One, beginning in this and extending into following sections I shall present certain key passages from Goffman that, although largely neglected, nevertheless provide important new glimpses into the Durkheimian core. Two, I shall attempt to pull together the loose strands of Goffman's thought (as alluded to above and as discussed in, e.g., Alexander 1987; Giddens 1981, 1988; and Williams 1988) through an interpretive matrix informed primarily by Jurgen Habermas and Stanford Lyman. 
nature of morality, especially within the realm of face-to-face interaction.

The crucial passage is contained within Goffman's discussion of "sign situations," that is, the unique array of information relaying, processing, monitoring, and control that emerges whenever persons enter into each other's immediate presence. The initial evaluations by each actor of the other's appearance, gestures, countenance, demeanor, and so forth provide a provisional definition of the situation. Within the context of this process of discovery and negotiation, however, Goffman (1953, p. 103) further suggests that

For the actor, others may come to be seen as sacred objects. The social attributes of recipients must be constantly honored; where these attributes have been dishonored, propitiation must follow... [The actor] must conduct himself with great ritual care, threading his way through one situation, avoiding another, counteracting a third, lest he unintentionally and unwittingly convey a judgment of those present that is offensive to them.

This is the beginning of Goffman's use of Durkheimian imagery.

Notice next Goffman's less than subtle jab at Mead and Weber, both of whom he accuses of placing an undue stress upon the instrumental or rational dimension of social action. This misguided view of action has, according to Goffman, caused these and other theorists to completely overlookindeed, even be blinded to-the actual moral fiber finely entwined in the rituals of face-to-face interaction. As Goffman (ibid.) explains,

The ritual model for social interaction has been poorly treated in the literature, perhaps because of the stress given by G. H. Mead and by Weber to the fact that a social relationship, and hence social interaction, was a product of two persons taking each other's actions into consideration in pursuing their own actions. This stress seems to have given an instrumental flavor to our thinking about the kinds of consideration we show in regard to others: the implication is that we take into consideration the actions of others (the better to achieve our personal ends, whatever these may be) and not so much that we give consideration to other per- 
sons. By "consideration" we have tended to mean calculation, not considerateness.

Goffman (1953, p. 104) continues in this same vein, citing along the way Durkheim's Elementary Forms of the Religious Life as providing the basis upon which this aspect of his dramaturgical theory has been forged:

A case may be made for the view that the best model for an object to which we give consideration is not a person at all, but a sacred idol, image or god. It is to such sacred objects that we show in extreme what we show to persons. We feel that these objects possess some sacred value, whether positive and purifying, or negative and polluting, and we feel disposed to perform rites before these objects. These rites we perform as frequently and compulsively as the sacred value of the object is great. These worshipful acts express our adoration, or fear, or hate, and serve for the idol as periodic assurances that we are keeping faith and deserve to be in its favor. When in the idol's immediate presence we act with ritual care, appreciating that pious actions may favorably dispose the idol toward us and that impious actions may anger the idol and cause it to perform angry actions against us. Persons, unless they are of high office, do not have as much sacred power or mana as do idols, and hence need not be treated with as much ceremony. An idol is to a person as a rite is to etiquette.

This last sentence is quite telling, because it helps explain Goffman's lifelong fascination with rules of etiquette, norms of politeness, access rituals, face engagements, territories of the self, body gloss, personal fronts, deference and demeanor, and on down the line. Also, those who are uncomfortable with what might be perceived as an overly optimistic or overextended analogy-that is, face-to-face interaction as a secularized form of religious ritual-can take comfort in Goffman's own clarification of the extent to which he is willing to carry it. "An idol is to a person as a rite is to etiquette" is an important part of understanding both how Goffman himself understands Durkheim and how in modern, secular society we continue to witness persons orienting themselves-for whatever reasontoward a perceived moral universe.

Next, a slight digression will be offered in the following two sections, one that retraces the Durkheim-to-Goffman link 
through a variety of important interpretations, the purpose of which is to tie together the loose strands of Goffman's intellectual lineage mentioned in the previous section.

\section{FROM DURKHEIM TO MEAD}

I spoke earlier of the two major components of Goffman's thought, namely the phenomenological and the sociological. It was suggested that Durkheim's sociology affords a bridge between these two formulations, the phenomenological or existential representing the "man" or "individual" (i.e., micro), and the sociological representing the "society" (i.e., macro) aspect of the problem. With this in mind we may now turn briefly to a related set of concerns with which Jurgen Habermas has dealt.

In a brilliant piece of theoretical synthesis, Habermas (1987) has made explicit much of what is implicit or embedded in Goffman, this by providing a bridge between Durkheim and Mead. ${ }^{5}$ We have already seen in Durkheim that religion is the outward manifestation of the collective consciousness. These ritual gatherings that reflect solidarity and group belief were observed as well by Mead in his theory of the development of personality. As Mead (1962) states, "It is where the 'I' and 'me' can in some sense fuse that there arises the peculiar sense of exaltation which belongs to the religious and patriotic attitudes in which the reaction which one calls out in others is the response which one is making himself."

Habermas (1987) thus suggests that both Mead and Durkheim were concerned with the linguistification of the sacred. First, Mead's theory of the development of the personality implicitly views religious symbolism as the archaic core of norm consciousness, because the move toward conceptualiz-

${ }^{5}$ Habermas (1984) accuses Goffman's dramaturgical theory of action of being one-sided in its emphasis on the strategic and goal-oriented nature of actors' selfpresentations. However, Habermas (1987, p. 46) also argues that Durkheim's notion of the collective consciousness is helpful for his own theoretical program insofar as it represents for Habermas a prelinguistic root of communicative action. So even though Habermas is overtly critical of Goffman, his discussion of Durkheim and the ontogenesis of ritual unwittingly reveals a positive relation between Durkheim and Goffman for which I am here attempting to argue. The relation between Habermas and Goffman-especially as mediated through Durkheim-is complex and cannot be pursued further here. For a very brief statement of the "Habermas-Goffman" problem, see Chriss (1992). 
ing the generalized other (through which the personality and the individual is forged) occurs only through and upon the acquisition of complex language or linguistic codes. Second, Durkheim's theory of societal progression emphasizes the scientization or rationalization of worldviews and the concomitant diminution of the religious force (Pickering 1984, p. 482). For Durkheim, rationalized codes of conduct such as the (explicit) rise of civil, restitutive law and the (implicit) cult of the individual exemplify the nature of modern society. With regard to both Mead and Durkheim, then, Habermas (1987, p. 46) states that "To the degree that the rationality potential ingrained in communicative action is released, the archaic core of the normative dissolves and gives way to the rationalization of worldviews, to the universalization of law and morality, and to the acceleration of processes of individuation. ${ }^{6}$

\section{FROM MEAD TO GOFFMAN}

The full implications of Mead's and Durkheim's views of ritual and the linguistification of the sacred will come to light only after completing another crucial progression of thought, this time from Mead to Goffman. For this I draw primarily from the works of Stanford Lyman (1990, 1991; Vidich and Lyman 1985).

Lyman's general theme is that the enlightenment ethos that resonates through the writings of those philosophers and social theorists being discussed here led each to a worldly rejection of religion. Our problem can be seen then as a double hermeneutic (Giddens 1979) or what Goffman (1974) has referred to as a frame within a frame: 1) social scientists struggling to understand and explain what is theorized to be a generalized and inexorable process, namely the secularization of society; and 2) caught up as they were in the spirit and ethos of their time, these same theorists felt the effects of the hypothesized rationalization of worldviews, the universalization of morality, etc., re-

${ }^{6}$ It is suggested that this rationalization of worldviews is a concomitant of Durkheim's theory of societal progression, namely, the shift from mechanical to organic solidarity. The cult of the individual is seen as arising through the prism of the division of labor and the continuing differentiation of tasks, thereby producing a new form of morality that is itself based upon the heightened interdependence of societal members. 
cursively in their own writings-this of course amounting to the worldly rejection of religion as a lived conviction.

Without going into great detail we could, following Vidich and Lyman (1985, p. 267), say that the intellectual lineage from Josiah Royce and Durkheim through Mead, Blumer, and finally Goffman illustrates that "the binding covenant of the [earlier] Protestant ethicists erodes in the face of the emergence of a plurality of worldly, nonbinding situational and personal ethics." Hence, for example, in place of Durkheim's collective conscience or community of individuals there is now polysymbolic interpretation (Vaitkus 1991) and unanchored selves, i.e., the cult of the individual.

If we can agree with Harry Johnson (1979, p. 313) that religion is "a kind of code, model or paradigm that shapes or patterns a more or less 'total' way of life: inner experience, action, and judgment," we see that each of our theorists was led to ask the same question: if in fact the religious force is on the wane, what is or will be the moral basis of an enlightenment society?

Vidich and Lyman (1985, p. 268) suggest that although they are all committed to some form of secularized (i.e., rationalized) thought, neither Royce's retreat into Pauline communitarianism nor Mead's collective will of the generalized other, nor even Blumer's conception of a secular ethics of the public interest are able to establish the kind of moral basis upon which societal members could orient their actions. This is because of the overly individualistic nature of the solution to the problem of how and by what process the individual becomes free from religious control toward the ultimate privatization of religion. In other words, as Habermas's (1987) linguistification of the sacred suggests, there must be some outwardly visible, binding ethos or morality-the total way of life once provided by religion-by which societal members could guide their actions.

Goffman's solution is to place the externalization of the moral code directly onto the structure of face-to-face interaction itself, thereby overcoming the theoretical complications arising from attempts to explicate or represent psychological processes of norm internalization. In one of his earlier papers,

7This idea of "unanchored selves" should not, however, be equated with unhealthy egoism, but rather should be seen as running closer to the spirit of the type of healthy individualism espoused by Durkheim. 
"The Nature of Deference and Demeanor," Goffman (1967, p. 47) outlines this approach and makes explicit his connection to Durkheim:

In this paper I want to explore some of the senses in which the person in our urban secular world is allotted a kind of sacredness that is displayed and confirmed by symbolic acts.... Through these reformulations I will try to show that a version of Durkheim's social psychology can be effective in modern dress.

What Goffman has hit upon is the rather straightforward notion that all societies have rules of conduct that are organized into codes by which individuals are or become aware of what types of acts are appropriate or inappropriate in whichever type of social setting. Whether ceremonial or substantive, these messages carried in acts or events say something about the degree to which individuals in the group understand or show appreciation for the nature of the gathering.

Durkheim (e.g., 1938, 1951, 1984) has shown that in preliterate societies the nature of individual action is constrained to the extent that it is relegated to a sort of mechanical acquiescence to the group. As stated earlier, this type of mechanical solidarity, oftentimes instantiated in religious ceremony or ritual, ensures that specific, sanctioned forms of conduct will emerge. At this stage-the mechanical form of solidarity-there is no conception of the individual, as even slight variations from the group norm can bring quick and harsh reprobation.

Durkheim's (1984) sociology of law emerged from his observations concerning the extent to which societal laws tend to be either repressive or restitutive. A premodern society with its concomitant form of mechanical solidarity would be characterized by (if any) punitive laws, whereas modern society with its organic solidarity would be characterized by restitutive law.

Goffman $(1967$, p. 90) of course realizes this as well, stating that "The rules of conduct which bind the actor and the recipient together are the bindings of society." His work thereby reveals what lies at the intersection of the sociology of religion and the sociology of law (Lyman 1990, 1991). Following from Durkheim's theory of the progression of society, Goffman depicts a social action predicated on the notion of a civil religion whose outward manifestations are the tacit set of rules and 
conventions-the rituals, if you will-guiding the course of face-to-face interaction. But unlike Mead's generalized other, Goffman's civil religion emphasizes that individuals are driven into self-presentation and -promotion. Society thereby has become primarily a species of communicative conduct wherein "each member presents what he hopes are efficacious excuses or justifications for acts called into question" (Vidich and Lyman 1985, p. 306; cf. Habermas 1987).

As we see, then, Durkheim and Goffman were both ultimately concerned with describing the conditions of social order, Durkheim at the macro level and Goffman, the micro level. ${ }^{8}$ Goffman's expansive illumination of categories and typologies of the various ways societal members navigate the conditions of the interaction order-through the revealing or concealing of secrets; the commitment, attachment, embracement, or role-distance to or from social or cultural objects; the handling of personal and use space; access rituals; accounts, apologies, remedial and supportive interchanges, face work; frames, fabrications, keyings; and through various forms of talk and the gestural and expressive signifiers that obtain-attests to the array of social tools available to individuals by which each may indicate the degree to which they are competent and willing to partake in the living of group life.

${ }^{8}$ MacCannell (1990) has made much the same point, arguing that Goffman's appropriation of Durkheim can be seen as the continuing attempt to delineate the external or visible (i.e., nonpsychological) factors-here being the interpersonal rituals of the interaction order-that operate in binding individuals to a moral code in the face of ongoing secularization. For a similar analysis of how ritual provides a link between the macro and micro, see Miller (1982).

${ }^{9}$ The point is that Goffman, like Durkheim, suggests that the individual has become the principal sacred object in secular society. The self, however, is not negotiated as in Mead or Blumer; rather, "...it is the archetypal modern myth. We are compelled to have an individual self not because we actually have one but because social interaction requires us to act as if we do" (Collins 1986, p. 107). See also Hannerz (1980), Berger (1973), and MacCannell (1990), each of whom discusses the appropriation by Goffman of Durkheim's notion of mana (soul). As the soul of the human being has become the focus of modern society, it is worshipped and considered worthy of awe as expressed through and by ritual attention. As Hannerz (1980, p. 210) explains, "People worship each other as little gods, in countless almost imperceptible ways; they become noticeable only in their absence, when the proper rituals are not performed and when the treatment given instead is seen as symbolic violence. The expression of acceptance of presented selves, at least within limits, thus becomes part of liturgy." 
The rituals in which members engage attest also to the sanctity of the individual, for each strip of action, though carried out on an individual basis, nevertheless conveys the collective nature of group life. As Goffman $(1967$, p. 42) has stated, "The ritual order seems to be organized basically on accommodative lines"; and further, by acquiring this ability to accommodate others "the person becomes a kind of construct, built up not from inner psychic propensities but from moral rules that are impressed upon him from without" (Goffman 1967, p. 45).

This accommodative function of the ritual order is especially salient with respect to Goffman's (1971) discussion of "maintenance rites." These are planned, repetitive gatherings that celebrate or reinforce contact between persons, thereby in turn serving symbolically to "guarantee the well-being of the relationship" (Goffman 1971, p. 73). Cheal (1988, pp. 98, 102, 106) has suggested that "rites of progression" (e.g., wedding anniversaries, birthdays, Mother's Day rituals) are concrete examples of the concepts we are here attempting to link: Goffman's maintenance rites and Durkheim's (1984, p. 122) "dignity of the human person" or, equivalently, "cult of the individual."

\section{AN APPLIGATION: EVANGELICALISM AND THE ETHIC OF GIVILITY}

Goffman's ideas concerning the accommodative function of the ritual order correspond as well with the concept of civil religion (e.g., Bellah 1964, 1967, 1970; Cuddihy 1978; Parsons 1978; Parsons and Platt 1973) and may be fruitfully applied to the case of Evangelicalism and "political civility" (Hunter 1983, $1984,1987) .{ }^{10}$ Cladis (1992, p. 76) sets the stage by explaining that

In an age marked by increased individualism and the eclipse of many traditional communities and social practices, Durkheim fears that the benefits of liberalism could be out-

${ }^{10}$ Both Parsons's “institutionalized individualism" and Bellah's "civil religion" are derived from Durkheim's cult of the individual, and for this reason share certain affinities with Goffman's ritual and interaction orders, namely the rejection of the utilitarian tradition that views the social actor from an individualistic and hyperrationalistic perspective (Tseelon 1992). 
weighed by its deleterious byproducts. He reminds us that when we inhabit the modern world (or worlds) we still receive many shared truths and goals. We live in a public world, a world not simply of our own, private making. Durkheim attempts to expose and strengthen those ties that join us to each other and to a common past and shared future. The rights and dignity of the individual are perhaps the most salient feature of our solidarity in modern democratic nations. Yet these are accompanied by various social commitments and obligations, and they need to be situated in a shared, moral context (call it democratic republicanism), lest they promote egoism instead of what Durkheim calls moral individualism, a common set of liberal dispositions and virtues.

As Hunter (1984, p. 364) has pointed out, virtually all of the world's religions manifest to some degree a radical wing of belief that, because it is so strongly committed to the doctrines and teachings of that particular religion, is apt to push its adherents toward engaging in aggressive political action. ${ }^{11}$ This phenomenon is certainly visible in the United States with regard to the political activities of certain factions within conservative Protestantism or Evangelicalism (such as the New Christian Right and the Moral Majority). Much of the political activity of the evangelicals, especially with regard to their attempts to mobilize support and affect legislation against such issues as the ERA, homosexuality, school prayer, and abortion (Hunter 1987), has led to the accusation from some corners that this group's "extremist policies and often violent political measures [may indeed] undermine national democratic processes and even international stability" (Hunter 1984, p. 364).

One of the great trends of modernism to which much of Durkheim's attention was drawn, especially as seen in the quote from Cladis above, has been the separation of church and state and the more general private/public split (Durkheim 1974; Hall 1987). This emphasis on the ethic of the separation between church and state, between religion and politics, has served to continually focus debate on the "proper" place of religion in a modern, "civil" society (Hunter 1987, p. 151).

${ }^{11} \mathrm{I}$ am indebted to an anonymous reviewer for bringing to my attention the work of James Hunter. 
Within the milieu of the civil society there exists as well a strong ethic of toleration, in this case, the overt support of the right of any group of worshipers to hold to their political, religious, or ideological beliefs, however "offensive" or distasteful these may appear to the society at large. It is suggested, for example, that sharp disagreement and open public debate on such issues is a sign of a healthy and tolerant democratic environment (i.e., the instantiation of Cladis's "democratic republicanism").

The important thing to note here is that this ethic of tolerance entails not only a general tolerance of others, but even more crucially in the case of Goffman's sociology, that individuals be tolerable to others (Hunter 1987, p. 152). Hence, as Hunter (1987, p. 153) has reported, the "pugnacious" and "incivil" tactics of such groups as the Moral Majority, Operation Rescue, and other evangelicals have become tempered somewhat in recent years by the simple realization that these breachings of the norm of political civility have done little to help their cause or endear themselves to the general public. ${ }^{12}$

Consider how Goffmanesque this "ethic of civility" (Cuddihy 1978) appears in Hunter's (1987, p. 152) description of the dilemmas faced by evangelicals in attempting to make public, through perhaps even "incivil" means, their particular set of religious and political beliefs:

This ethic [of civility] is an ethic of gentility and studied moderation. It speaks of a code of social discourse whereby religious beliefs and political convictions are to be expressed discreetely and tactfully and in most cases, privately. Convictions are to be tempered by "good taste" and sensibility. It is an ethic which pleads "no offense." The greatest breach of these norms is belligerence and divisiveness; the greatest atrocity is to be offensive and thus intolerable.

As we have already witnessed, Goffman, for much of his career, was concerned with cataloguing the many ways in which persons manage impressions of themselves before a group of oth-

${ }^{12}$ This phenomenon of accommodation is also evident in the recent rise of scientific creationism, a movement that attempts to debate the theory of evolution and the creation not only from a theological perspective, but also from within the mcre secular and humanist discourses of science (Eckberg 1992). 
ers. ${ }^{13}$ These routines of everyday life, these ceremonial and substantive rituals played out on the public and private stage whereby persons exhibit through deference and demeanor the obligations and expectations of their group or society, were for Goffman the defining moment in the understanding of social order in general (Stein 1991, p. 422). The rituals of face-to-face conduct, especially as these involve the attempt to accommodate persons so as to avoid overt hostility and confrontation, are the direct descendant of the type of moral and ethical codes carried in Durkheim's cult of the individual or, alternately, respect for the human person.

For Goffman (1967, p. 45), the rituals of daily life themselves provide the basis upon which a moral career is established. He states that

The general capacity to be bound by moral rules may well belong to the individual, but the particular set of rules which transforms him into a human being derives from requirements established in the ritual organization of social encounters.

For this to work Goffman must bank heavily on Durkheim's suggestion that through ritual individuals produce and reproduce moral sentiments. The affective or expressive components elicited as a result of the social gathering are tied symbolically to, or equated with, the ritual work itself, thereby creating a form of sociation or consciousness that helps to perpetuate the moral code within each individual as a lived conviction. In this light Collins (1988, p. 46) argues that for Goffman "Everyday life is a ritual: this is a direct extension of the Durkheimian argument. And the primary sacred object, elevated to symbolic status by the way rituals are structured in everyday life, is the self."

In analyzing Goffman's sociology through Durkheim's cult of the individual, then, I have attempted to deny the extent to

${ }^{13}$ As Burns (1992, p. 27) explains, Goffman's conception of the "interaction order" amounts "to the recognition by people of an obligation to display what used to be called 'civility' or 'good manners'-socially acceptable or 'proper' behaviour-in the presence of others. ... The highest common factor, so to speak, is no more than the practice of behaving predictably, or refraining from causing offence to other people, or not obstructing or interfering with their presence, passage or utterance, either actual or intended." 
which many writers have placed Goffman in the utilitarian or individualistic camp (e.g., Alexander [1987] and Habermas [1984], but cf. Rawls [1987]). By illustrating his deep connections to Durkheim, I have shown how Goffman's interaction order, built up as it is from the vast array of interpersonal rituals contained therein, serves as a continuation of Durkheim's ideas concerning the sanctity of the individual and the progression of modern society. Both Durkheim and Goffman were concerned with describing how modern individualism is based, not so much on the strategic action of utilitarian social philosophy, but, rather, on the sort of morality arising, nearly in "sui generis" fashion (Rawis 1987), from the exigencies of faceto-face interaction and group life. In fact, Schoenfeld and Mestrovic's (1991, p. 84) defense of Durkheim, in this regard, can be equally applied to Goffman: "In sum, Durkheim sought to depict a form of individualism that is far removed from utilitarian, egoistic, self-interested depictions of the human person found in most discourse on this topic."

\section{REFERENCES}

Alexander, Jeffrey C. 1987. Twenty Lectures: Sociological Theory Since World War II. New York: Columbia University Press.

Bellah, Robert N. 1964. "Religious Evolution." American Sociological Review 29:358-374.

Bellah, Robert N. 1967. "Civil Religion in America." Daedalus 96(1):121.

Bellah, Robert N. 1970. Beyond Belief: Essays on Religion in a PostTraditional World. New York: Harper \& Row.

Berger, Bennett M. 1973. "A Fan Letter on Erving Goffman." Dissent 20:353-361.

Burns, Tom. 1992. Erving Goffman. London: Routledge.

Cheal, David J. 1988. "Relationships in Time: Ritual, Social Structure, and the Life Course." Studies in Symbolic Interaction 9:83-109.

Chriss, james J. 1992. "Habermas and Goffman: Some Suggestions for Future Research." Perspectives: The Theory Section Newsletter 15(3):6.

Cladis, Mark S. 1992. "Durkheim's Individual in Society: A Sacred Marriage?" Journal of the History of Ideas 53(1):71-90.

Collins, Randall. 1975. Conflict Sociology: Towards an Explanatory Science. New York: Academic Press.

Collins, Randall. 1980. "Erving Goffman and the Development of 
Modern Social Theory." Pp. 170-209 in The View from Goffman, edited by J. Ditton. New York: St. Martin's.

Collins, Randall. 1986. "The Passing of Intellectual Generations: Reflections on the Death of Erving Goffman." Sociological Theory 4:106-113.

Collins, Randall. 1988. "Theoretical Continuities in Goffman's Work." Pp. 41-63 in Erving Goffman: Exploring the Interaction Order, edited by Paul Drew and Anthony Wootton. Boston: Northeastern University Press.

Collins, Randall and Michael Makowsky. 1972. The Discovery of Society. New York: Random House.

Cuddihy, John Murray. 1978. No Offense: Civil Religion and Protestant Taste. New York: Seabury.

Durkheim, Emile. 1938. The Rules of Sociological Method, translated by S. A. Solovay and J. H. Mueller. Chicago: University of Chicago Press.

Durkheim, Emile. 1951. Suicide, translated by J. Spaulding and G. Simpson. Glencoe: Free Press.

Durkheim, Emile. 1954. The Elementary Forms of the Religious Life, translated by J. Swain. Glencoe: Free Press.

Durkheim, Emile. 1957. Professional Ethics and Civic Morals, translated by C. Brookfield. London: Routledge \& Kegan Paul.

Durkheim, Emile. 1961. Moral Education, translated by E. K. Wilson and $H$. Schnurer. Glencoe: Free Press.

Durkheim, Emile. 1974. Sociology and Philosophy, translated by D. F. Pocock. New York: Free Press.

Durkheim, Emile. 1984. The Division of Labor in Society, translated by W. D. Halls. New York: Free Press.

Eckberg, Douglas Lee. 1992. "Social Influences on Belief in Creationism." Sociological Spectrum 12(2):145-165.

Giddens, Anthony. 1979. Central Problems in Social Theory. London: Macmillan.

Giddens, Anthony. 1981. "Agency, Institution, and Time-Space Analysis." Pp. 161-174 in Advances in Social Theory and Methodology, edited by K. Knorr-Cetina and A. V. Cicourel. Boston: Routledge \& Kegan Paul.

Giddens, Anthony. 1988. "Goffman as a Systematic Social Theorist." Pp. 250-279 in Erving Goffman: Exploring the Interaction Order, edited by Paul Drew and Anthony Wootton. Boston: Northeastern University Press.

Goffman, Erving. 1953. "Communication Conduct in an Island Community." Ph.D. diss., University of Chicago.

Goffman, Erving. 1959. The Presentation of Self in Everyday Life. Garden City, NJ: Doubleday. 
Goffman, Erving. 1961a. Asylums. Garden City, Nj: Anchor.

Goffman, Erving, 1961b. Encounters. Indianapolis: Bobbs-Merrill.

Goffman, Erving, 1963a. Stigma. Englewood Cliffs, NJ: Prentice-Hall.

Goffman, Erving. 1963b. Behavior in Public Places. New York: Free Press.

Goffman, Erving. 1967. Interaction Ritual. Chicago: Aldine.

Goffman, Erving, 1969. Strategic Interaction. Philadelphia: University of Philadelphia Press.

Goffman, Erving. 1971. Relations in Public. New York: Basic Books.

Goffman, Erving. 1974. Frame Analysis. New York: Harper \& Row.

Goffman, Erving. 1979. Gender Advertisements. New York: Harper \& Row.

Goffman, Erving. 1981. Forms of Talk. Philadelphia: University of Pennsylvania Press.

Habermas, Jurgen. 1984. The Theory of Communicative Action, Vol. 1, translated by T. McCarthy. Boston: Beacon Press.

Habermas, Jurgen. 1987. The Theory of Communicative Action, Vol. 2, translated by T. McCarthy. Boston: Beacon Press.

Hall, Robert T. 1987. Emile Durkheim: Ethics and the Sociology of Morals. New York: Greenwood Press.

Hannerz, Ulf. 1980. "The City as Theater: Tales of Goffman." Pp. 202241 in Exploring the City: Inquiries Toward an Urban Anthropology. New York: Columbia University Press.

Hunter, James Davison. 1983. American Evangelicalism: Conservative Religion and the Quandary of Modernity. New Brunswick, N]: Rutgers University Press.

Hunter, James Davison. 1984. "Religion and Political Civility: The Coming Generation of American Evangelicals." Journal for the Scientific Study of Religion 23(4):364-380.

Hunter, James Davison. 1987. Evangelicalism: The Coming Generation. Chicago: University of Chicago Press.

Johnson, Harry M. 1979. "Religion in Social Change and Social Evolution." Pp. 313-339 in Religious Change and Continuity: Sociological Perspectives, edited by $\mathrm{H}$. Johnson. San Francisco: Jossey-Bass.

Lukes, Steven. 1972. Emile Durkheim: His Life and Work. New York: Harper \& Row.

Lyman, Stanford M. 1990. Civilization: Contents, Discontents, Malcontents, and Other Essays in Social Theory. Fayetteville: University of Arkansas Press.

Lyman, Stanford M. 1991. "Animal Faith, Puritanism, and the SchutzGurwitsch Debate." Human Studies 14(2-3):199-206.

MacCannell, Dean. 1983. "Erving Goffman (1922-1982)." Semiotica 45(1/2):1-33. 
MacCannell, Dean. 1990. "The Descent of the Ego." Pp. 19-39 in Beyond Goffman: Studies on Communication, Institution, and Social Interaction, edited by S. H. Riggins. Berlin: Mouton de Gruyter.

Marske, Charles E. 1987. "Durkheim's 'Cult of the Individual' and the Moral Reconstitution of Society." Sociological Theory $5(1): 1-14$.

Mead, George H. 1962. in Mind, Self, and Society, edited by C. Morris. Chicago: University of Chicago Press.

Mestrovic, Stjepan G. 1988. Emile Durkheim and the Reformation of Sociology. Totowa, NJ: Rowman \& Littlefield.

Miller, Diane L. 1982. "Ritual in the Work of Durkheim and Goffman: The Link Between the Macro and the Micro." Humanity and Society 6:122-134.

Mitchell, Jack N. 1978. Social Exchange, Dramaturgy and Ethnomethodology: Toward a Paradigmatic Synthesis. New York: Elsevier.

Parsons, Talcott. 1978. Action Theory and the Human Condition. New York: Free Press.

Parsons, Talcott and Gerald M. Platt. 1973. The American University. Cambridge, MA: Harvard University Press.

Pearce, Frank. 1989. The Radical Durkheim. London: Unwin Hyman.

Pickering, W. S. F. 1984. Durkheim's Sociology of Religion: Themes and Theories. London: Routledge \& Kegan Paul.

Rawls, Anne W. 1987. “The Interaction Order Sui Generis: Goffman's Contribution to Social Theory." Sociological Theory 5(2):136149.

Schoenfeld, Eugen and Stjepan G. Mestrovic. 1991. "From the Sacred Collectivity to the Sacred Individual: The Misunderstood Durkheimian Legacy." Sociological Focus 24(2):83-92.

Stein, Michael. 1991. "Sociology and the Prosaic." Sociological Inquiry 61(4):421-433.

Tiryakian, Edward. 1961. Sociologism and Existentialism. Englewood Cliffs, NJ: Prentice-Hall.

Tiryakian, Edward. 1978. "Emile Durkheim." Pp. 187-236 in A History of Sociological Analysis, edited by T. Bottomore and R. Nisbet. New York: Basic Books.

Tseelon, Efrat. 1992. "Is the Presented Self Sincere? Goffman, Impression Management and the Postmodern Self." Theory, Culture \& Society 9(2):115-128.

Vaitkus, Steven. 1991. How Is Society Possible? Dordrecht, The Netherlands: Kluwer Academic.

Vidich, Arthur J. and Stanford M. Lyman. 1985. American Sociology: 
Worldly Rejections of Religion and Their Directions. New Haven, CT: Yale University Press.

Williams, Robin. 1988. "Understanding Goffman's Method." Pp. 6488 in Erving Goffman: Exploring the Interaction Order, edited by Paul Drew and Anthony Wootton. Boston: Northeastern University Press. 